University of Nebraska - Lincoln

DigitalCommons@University of Nebraska - Lincoln

Papers in the Earth and Atmospheric Sciences

Earth and Atmospheric Sciences, Department

August 2001

\title{
Experimental Diatom Dissolution and the Quantification of Microfossil Preservation in Sediments
}

D. B. Ryves

University College London, dr@geus.dk

S. Juggins

University of Newcastle

Sherilyn C. Fritz

University of Nebraska-Lincoln, sfritz2@unl.edu

R. W. Battarbee

University College London

Follow this and additional works at: https://digitalcommons.unl.edu/geosciencefacpub

Part of the Earth Sciences Commons

Ryves, D. B.; Juggins, S.; Fritz, Sherilyn C.; and Battarbee, R. W., "Experimental Diatom Dissolution and the Quantification of Microfossil Preservation in Sediments" (2001). Papers in the Earth and Atmospheric Sciences. 39.

https://digitalcommons.unl.edu/geosciencefacpub/39

This Article is brought to you for free and open access by the Earth and Atmospheric Sciences, Department of at DigitalCommons@University of Nebraska - Lincoln. It has been accepted for inclusion in Papers in the Earth and Atmospheric Sciences by an authorized administrator of DigitalCommons@University of Nebraska - Lincoln. 
Published in Palaeogeography, Palaeoclimatology, Palaeoecology 172:1-2 (August 1, 2001), pp. 99-113; doi 10.1016/S0031-0182(01)00273-5 http://www.sciencedirect.com/science/journal/00310182

Copyright (C) 2001 Elsevier Science B.V. Used by permission

Submitted December 2, 1999; accepted April 4, 2001; published online July 25, 2001.

\title{
Experimental Diatom Dissolution and the Quantification of Microfossil Preservation in Sediments
}

\author{
D. B. Ryves ${ }^{a}, *$, S. Juggins ${ }^{b}$, S. C. Fritz ${ }^{c}$, and R. W. Battarbee ${ }^{a}$ \\ a Environmental Change Research Centre, \\ University College London, 26 Bedford Way, London, WC1H 0AP, UK \\ b Department of Geography, University of Newcastle, Newcastle-upon-Tyne, NE1 7RU, UK \\ ${ }^{c}$ Department of Geosciences, University of Nebraska-Lincoln, Lincoln, NE 68588, USA \\ * Corresponding author. Present address: Department of Environmental History \& Climate Change, \\ Geological Survey of Denmark \& Greenland (GEUS), Thoravej 8, DK-2400 Copenhagen NV, Denmark. \\ Fax: 45 38-142050; email: dr@geus.dk
}

\begin{abstract}
Four laboratory experiments on fresh, modern diatoms collected from lakes in the Northern Great Plains of North America were carried out to assess the effects of dissolution on diatom abundance and composition. Marked differences in mean dissolution susceptibility exist between species, despite sometimes significant intra-specific variation between heterovalves. Twenty-four taxa were ranked according to susceptibility to dissolution using an exponential decay model of valve abundance. This dissolution ranking was used to derive two weighted indices of sample preservation.

A third index $(F)$ was based on a simple binary classification of valve morphology into dissolved and pristine categories, as distinguished by light microscopy (LM). When compared against rank indices and a measure of species diversity, this diatom dissolution index was found to be the best predictor of the progress of dissolution as estimated by total valve abundance or biogenic silica (BiSi) loss. Strong empirical relationships between $F$ index values and diatom abundance $\left(r^{2}=0.84, n=32\right)$ and $\mathrm{BiSi}\left(r^{2}=0.89, n=32\right)$ were developed and applied to a diatom sequence from a short core from Devils Lake, North Dakota, and compared to diatominferred and observed salinity at this site.

The $F$ index is a simple, effective diagnostic tool to assess important aspects of diatom preservation. The index can provide insight into Si cycling and record changes in conditions pertinent to diatom dissolution, and has a role in validation of transfer functions or other inferences derived from compositional data.
\end{abstract}

Keywords: diatoms, experimental studies, taphonomy, dissolution, northern Great Plains, reconstruction

\section{Introduction}

Microfossil assemblages in marine and lacustrine sediments have been extensively employed to reconstruct past environments, especially with the development of transfer functions for quantitative inferences of climatic and hydrochemical parameters (Imbrie and Kipp 1971; Birks et al. 1990; Guiot
1990; Fritz et al. 1991; Gasse et al. 1995). Such environmental reconstructions are limited by the quality of the original data from which they are derived. In particular, differential preservation can severely affect the composition of microfossil assemblages, potentially compromising their usefulness in making reliable paleoenvironmental inferences (Berger 1968; Barker et al. 1990). This is a common prob- 
lem for diatom analysis in saline systems, both marine (Samtleben et al., 1995) and continental (athalassic) (Barker et al., 1994), although poor diatom preservation is not confined to saline environments (Round, 1964).

Poor preservation of diatoms in saline lakes is predominantly the result of biogenic silica (BiSi) dissolution, which has a range of effects on an assemblage. In extreme cases, the assemblage may be entirely destroyed but where dissolution is incomplete, differential dissolution of valves and taxa may bias the composition of species within a sample and thus affect the environmental inferences.

Although there is abundant anecdotal evidence for marked differences between taxa in resistance to dissolution, quantifying these relationships is extremely difficult. Previous experimental work has quantified amorphous silica dissolution in solutions that vary in $\mathrm{pH}$, temperature, salt concentration and ionic composition (e.g. Lewin 1961; Marshall and Warakomski 1980; Hurd et al. 1981; Barker et al. 1994). Kinetic rates of dissolution are related to the degree of saturation of the dissolving medium (and are non-linear at high undersaturation; van Cappellen and Qiu, 1997). Factors intrinsic to the silica solid are also important, notably the surface area of reactive solid per unit mass (the specific surface area) and the total area available for dissolution per unit volume of solution (Hurd et al., 1981). Dissolution rates are also sensitive to organic matter and metal ions associated with the frustule surface (Lewin 1961; van Bennekom, 1980; Mayer et al. 1991). Experimental dissolution rates tend to fall in closed-system experiments over time, as available surface area per unit volume and degree of solution under saturation decrease (Erez et al. 1982; Kamatani et al. 1988).

Changes in relative species abundance have been used to construct rank ordering systems, and to derive preservation indices for microfossil assemblages (samples) (Berger 1968; Mikkelsen 1980). Relative susceptibility ranking has also been used to construct indices of sample dissolution, based on presence, absence, or weighted abundances of taxa from each ranked group (e.g. Peterson and Prell 1985; Shemesh et al. 1989; McMinn 1995). Absolute ranking systems have also been developed by standardizing relative abundance changes to one taxon (Johnson, 1974) or by comparing the loss rates of different taxa during dissolution experiments (Adelseck, 1978). Rank orderings are not always comparable, because they are sensitive to differences in initial condition of valves. Preservation states may differ not only between fresh and subfossil (sedimentary) material, but also amongst sedimentary samples from different depths or locations. Dissolution processes in sediments can also be complicated by mineral silicate buffering and trace-metal interactions.

In many marine surface-sediment studies, the proportion of robust species has been used to assess preservation of individual samples (e.g. Peterson and Prell 1985; Shemesh et al. 1989; Pichon et al. 1992). This approach gives a qualitative indication of sample preservation, but comparison between sites or levels is difficult when the original living communities, and resultant death assemblages, differ.

Morphological changes can also be used as a measure of microfossil preservation (Beyens and Denys, 1982). For example, McIntyre and McIntyre (1971) observed a sequence of degradation for several heterococcoliths from deep-sea core tops and experiments, and ranked the taxa according to physical resistance to destruction. More recently, Battarbee (1988), Barker (1992), Flower (1993), and Barker et al. (1994) have demonstrated steps in the dissolution process for several diatom taxa and used these stages to construct dissolution indices (Barker et al. 1994; Flower and Likhoshway, 1993), based on changes in diatom morphology caused by dissolution.

This paper evaluates two approaches for assessing diatom preservation in athalassic lakes using a series of laboratory dissolution experiments on fresh diatoms from subsaline to saline lakes in the Northern Great Plains of North America (Fritz et al., 1993). Such experiments can act as analogues for the taphonomic processes of diatom dissolution in lake and sedimentary environments. Results from these experiments are used to develop a dissolution ranking system based on non-linear regression modeling of abundance changes of individual taxa. The performance of two preservation indices derived from this ranking are compared with the one based on a simple morphological classification of valves. Experimental results are applied in a paleoenvironmental context to a core from Devils Lake, North Dakota (Fritz, 1990). 


\section{Methods}

\subsection{Experimental design}

Diatom taxa found in a 55 lake surface-sediment dataset from the Northern Great Plains (Fritz et al., 1999) were chosen for dissolution experiments, and fresh material collected from a total of 46 regional lakes in August 1991 and September 1992 (detailed in Ryves, 1994). Two taxa (Amphora libyca and $\mathrm{Na}$ vicula oblonga) that were not found during fieldwork were sampled from lakes in the UK. Dissolution experiments reported here use a subset of samples from 14 lakes, using material collected from epiphytic, epilithic and epipsammic habitats only. Lake salinity varied from 0.9 to $38.6 \mathrm{~g} \mathrm{l}^{-1}$ total dissolved solids (TDS). Most lakes were $\mathrm{Mg} / \mathrm{NaSO}_{4}$ systems, although some included significant amounts of $\mathrm{CO}_{3}$ or $\mathrm{Cl}$ anions.

All fresh samples were treated with Lugol's iodine or $4 \%$ glutaraldehyde (glutaric dialdehyde) solution in the field and stored in coolers until refrigerated in the dark at $4^{\circ} \mathrm{C}$ in the laboratory. In addition, on collection epipsammon samples were gently washed in lake water to minimize sedimentary contamination. In the laboratory, all samples were oxidized with $30 \% \mathrm{H}_{2} \mathrm{O}_{2}$ at $80-85^{\circ} \mathrm{C}$ for up to $4 \mathrm{~h}$, without adding concentrated $\mathrm{HCl}$, which has been shown to strip dissolution-retarding metal ions from silica surfaces (Lewin, 1961) and affects sample preservation (Flower, 1993). An experimental method was developed on cleaned frustules (Ryves, 1994) to optimize dissolution rate and sample size while minimizing processing losses (Figure 1).

Four experimental assemblages were made by mixing between three and seven cleaned samples from epilithon and epiphyton communities, with epipsammon also used in assemblage 1 . These were combined to yield final mixtures dominated by only a few taxa, although the total species diversity was much larger. Species composition and abundance was verified on a subsample from each assemblage prior to beginning the experiment. BiSi content of each assemblage was estimated by digesting up to six subsamples of different sizes in $0.2 \mathrm{M} \mathrm{NaOH}$ at $85^{\circ} \mathrm{C}$ for 30 min (modified from Krausse et al., 1983), which microscopic examination showed was sufficient to dissolve all valves (Ryves, 1994). Initial BiSi in each dissolution experiment was chosen so that maximum dissolved silica (DSi) concentrations would be well below saturation (for amorphous silica, $160 \mathrm{mg} \mathrm{l}^{-1}$ Si or $\sim 5800 \mu \mathrm{M}$ Si at $\mathrm{pH} 10$ and $25^{\circ} \mathrm{C}$; Krauskopf, 1982). Initial assemblage populations ranged from 12 to $48 \times 10^{6}$ valves, with initial assemblage BiSi values between 0.114 and $0.201 \mathrm{mg} \mathrm{Si} / 10^{6}$ valves.

Dissolution was carried out in stoppered highdensity polyethylene flasks, in a covered water-bath shaker at $25^{\circ} \mathrm{C}$ in distilled water buffered at $\mathrm{pH} 10$ for between four and seven weeks in two experimental runs (Figure 1). Assemblages 1-3 were used in the first experiment and 4 in the second. A spike of synthetic microspheres (Battarbee and Kneen, 1982) was added to each flask to give an initial microsphere/diatom ratio of about 0.25 , which would increase as the diatoms dissolved. A small amount of mercury(II) chloride $\left(\mathrm{HgCl}_{2}\right)$ was added to each flask to inhibit the growth of bacteria or other micro-organisms, which can promote both BiSi (Patrick and Holding 1985; Bidle and Azam 1999) and carbonate dissolution (Freiwald, 1995). The control sample for each assemblage (sample 1) was taken immediately (1-3: $t_{1}=1.2 \mathrm{~h} ; 4: t_{1}=0.05 \mathrm{~h}$ ).

Thoroughly mixed samples of $10 \mathrm{ml}$ were taken with an Eppendorf pipette at selected intervals (see Figure 1) during each experiment and analyzed for supernatant DSi concentration. The spectrophotometric method of Golterman et al. (1978) was used, which they report may attain both accuracy and precision of $1-2 \%$. Similar values were found on replication of standards and some samples from other dissolution experiments (Ryves, 1994). After neutralizing the buffer solution, valve abundance in each sample was assessed using an inverted microscope (Lund et al., 1958) after validation of the method (Ryves, 1994). Eight sample points (including the control; highlighted in Figure 1) within each experiment were chosen for detailed diatom analysis using both oilimmersion phase-contrast light microscopy (LM) at $1000 \times$ on at least 400 valves (unless badly dissolved, where a minimum of 150 valves were counted) and scanning electron microscopy (SEM).

A short ${ }^{210} \mathrm{~Pb}$-dated sediment core from Devils Lake, North Dakota, was chosen as a paleolimnological application as there is both a diatom-inferred (DI) and measured salinity record for this site (Fritz, 1990) through most of the 1900s. Additionally, live diatom 


\section{Experimental design}

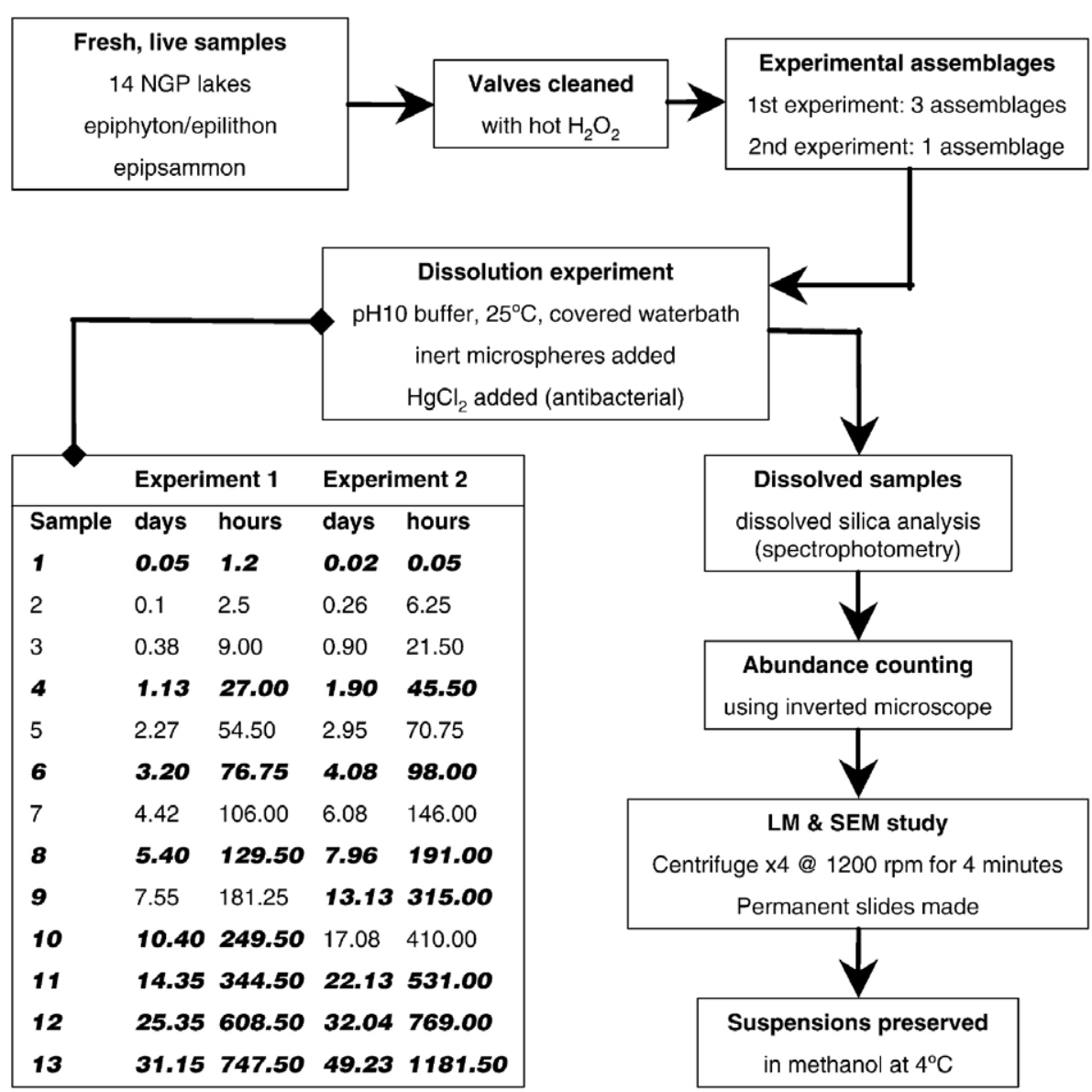

Figure 1. Schematic flow chart of design and procedure for dissolution experiments. Samples chosen for detailed LM analysis are indicated.

samples from this site were included in present experiments. Original slides from the 19 uppermost levels were recounted to estimate assemblage diatom dissolution, based on 150-350 valves per sample. Although several salinity models from the Northern Great Plains have been published (Fritz 1990; Fritz et al. 1991; Fritz et al. 1993), that of Fritz (1990) is used as DI values are closest to those observed at Devils Lake (Ryves and Battarbee, 1997).

\subsection{Dissolution ranking}

To compare diatom dissolution susceptibility between assemblages and develop an absolute ranking system, non-linear regression modeling was applied to the observed decline in valve abundance. Only taxa with $>3 \%$ in initial samples were modeled to reduce the effect of counting errors on estimation of initial numbers. The compositional data for each such taxon were transformed to absolute values, which were divided by the initial (control) population to give the proportion of the initial population for each sample. These data were modeled using an exponential decay function of the form:

$$
p_{i(t)}=\alpha \mathrm{e}^{-\beta t}
$$

where $p_{i(t)}$ is the percentage of valves of taxon $i$ at time $t$, compared to the population at time $t_{1}$ (control sample), and $\alpha$ and $\beta$ are constants. If well-modeled, the parameter $\beta$ determines the rate at which a diatom 
population disappears from the assemblage. Larger $\beta$ values are associated with finer, more susceptible taxa, which disappear quickly, and small values with robust forms. The time taken for the population to fall by $50 \%$ (the "dissolution half-life," [ $[\ln 2] / \beta$ ) was used as a measure of resistance and calculated for each significant case. Comparing $\beta$ values (or their derivatives) is thus a method of ranking taxa along a floating scale, which maintains the absolute ratio of species dissolution resistance. The significance of the fitted $\beta$ values was assessed using a one-tailed $t$-test (i.e. $\beta>0, p=0.05$ ).

\subsection{Dissolution indices}

\subsubsection{Morphological dissolution index}

Valves were classified into one of the two dissolution categories depending on whether they were visibly dissolved or not under LM. A simple fractional dissolution index, $F$, developed from Flower and Likhoshway (1993), was calculated as the proportion of non-dissolved (or "pristine") to all classifiable valves within an assemblage:

$$
F_{i}=\frac{\sum_{j}^{m} n_{i j}}{\sum_{j}^{m} N_{i j}}
$$

where $n_{\mathrm{ij}}$ is the number of pristine valves of species $j$ (of $m$ ) counted in a sample $i$, compared to $N_{\mathrm{ij}}$, the total number of classifiable valves of species $j$. $F$ varies between 0 (all valves visibly dissolved) and 1 (perfect preservation) and is useful for comparing different assemblages. $F$ cannot discriminate between samples in which all valves are visibly dissolved ( $F$ $=0$ ), but where the degree of dissolution may differ (Ryves, 1994).

Generally, 90-95\% or more of valves in experimental or fossil samples could be classified. The main exceptions were girdle views and smaller fragments. Emphasis is placed here on assemblage dissolution indices because these reflect average valve conditions and are based on greater valve counts, although species dissolution indices were also calculated (Table 1; Ryves, 1994). Breakage is linked to dissolution as dissolved valves break more eas- ily, and vice versa, but was not explicitly included in the index.

\subsubsection{Rank dissolution index}

Rank data can also be used to create indices of dissolution for samples $(R)$, by weighting species according to (relative) abundance, analogous to the $F$ index for samples in Equation (2), as follows:

$$
R_{i}=\frac{\sum_{j}^{m} r_{j} y_{i j}}{\sum_{j}^{m} y_{i j}}
$$

where $y_{i j}$ is the (relative) abundance of species $j$ in sample $i$ with rank $r_{j}$, which can be the absolute $\left(R_{\mathrm{w}}\right)$ or grouped rank $\left(R_{\mathrm{wg}}\right)$. On the basis of experimental data reported here (Table 1), 24 taxa were assigned ranks, and merged into five groups, rank 1 being the most resistant. The weighted average is taken for all taxa assigned a rank in the sample. High sample values of $R$ imply assemblages typified by dissolutionsusceptible taxa, and vice versa.

\section{Results}

\subsection{Dissolution experiments}

Species composition changes and sample dissolution parameters (including $F, R_{\mathrm{w}}$, and $R_{\mathrm{wg}}$ ) for the four assemblages are presented in Figure 2. Relative abundance of taxa occurring over $5 \%$ in any sample are plotted against experimental time (h). Hill's $N_{2}$ is also included as a measure of change in assemblage structure. $N_{2}$ estimates the effective number of species per sample, as the inverse of Simpson's diversity index (Hill, 1973).

\subsubsection{Assemblage composition changes over time} In all assemblages, large and robust forms (e.g. Amphora libyca, Navicula oblonga, Mastogloia spp.) tend to increase their relative abundance throughout, while more delicately structured taxa (e.g. small species such as Achnanthes minutissima and finer Nitzschia spp.) disappear. Some taxa (e.g. C. placentula var. lineata, assemblage 2) maintain a similar proportion throughout and disappear at the av- 
Table 1. Experimental ranking of resistance to dissolution for 24 taxa from the Northern Great Plains. Taxa are ranked according to (weighted) $\beta$ values from an exponential model of population decline (Equation (1)). Half-life (theoretical time under dissolution conditions at which $50 \%$ of number are dissolved), resistance relative to $N$. fonticola and initial taxon $F$ value $\left(F_{0}\right)$ are also given.

\begin{tabular}{|c|c|c|c|c|c|c|}
\hline Order & Group & Name & $\beta\left(10^{-3}\right)$ & Half-life (h) & Relative resistance & $F_{0}$ \\
\hline 1 & 1 & Mastogloia elliptica var. dansei & 0.46 & 1513 & 21.37 & 0.84 \\
\hline 2 & 1 & Nitzschia amphibia & 0.86 & 811 & 11.45 & 0.98 \\
\hline 3 & 1 & Cocconeis placentula var. lineata + & 0.91 & 761 & 10.75 & 0.94 \\
\hline 4 & 1 & Navicula oblonga & 1.03 & 672 & 9.49 & 0.75 \\
\hline 5 & 1 & Gomphonema parvulum & 1.20 & 578 & 8.16 & 0.82 \\
\hline 6 & 2 & Cocconeis placentula var. lineata - & 1.48 & 469 & 6.62 & 0.70 \\
\hline 7 & 2 & Fragilaria lapponica & 1.52 & 457 & 6.45 & 1.00 \\
\hline 8 & 2 & Gomphonema olivaceum & 1.55 & 447 & 6.32 & 0.97 \\
\hline 9 & 2 & Amphora libyca & 1.74 & 399 & 5.64 & 0.95 \\
\hline 10 & 2 & Cocconeis pediculus - & 1.75 & 396 & 5.59 & 0.85 \\
\hline 11 & 2 & Amphora pediculus & 2.02 & 342 & 4.84 & 1.00 \\
\hline 12 & 3 & Rhopalodia gibba & 2.80 & 248 & 3.50 & 0.88 \\
\hline 13 & 3 & Cymbella pusilla & 3.13 & 221 & 3.12 & 0.96 \\
\hline 14 & 3 & Cocconeis placentula var. euglypta + & 3.39 & 205 & 2.89 & 0.98 \\
\hline 15 & 3 & Cocconeis pediculus + & 3.57 & 194 & 2.74 & 0.86 \\
\hline 16 & 4 & Cocconeis placentula var. euglypta - & 4.22 & 164 & 2.32 & 1.00 \\
\hline 17 & 4 & Nitzschia frustulum & 4.23 & 164 & 2.32 & 1.00 \\
\hline 18 & 4 & Diatoma moniliformis & 4.59 & 151 & 2.13 & 1.00 \\
\hline 19 & 4 & Achnanthes minutissima & 5.17 & 134 & 1.89 & 1.00 \\
\hline 20 & 4 & Cyclotella meneghiniana & 6.45 & 107 & 1.52 & 1.00 \\
\hline 21 & 4 & Opephora [cf. olsenii] & 6.53 & 106 & 1.50 & 1.00 \\
\hline 22 & 5 & Nitzschia palea & 9.61 & 72 & 1.02 & 0.97 \\
\hline 23 & 5 & Nitzschia fonticola & 9.79 & 71 & 1.00 & 0.98 \\
\hline 24 & 5 & Cyclotella choctawhatcheeana & 14.80 & 47 & 0.66 & 0.00 \\
\hline
\end{tabular}

erage rate for the total assemblage. Differences in heterovalvar susceptibility of raphid (coded as “+”) and araphid (coded as "-") valves of the same species were evident. In assemblage 4, for instance, Cocconeis pediculus, present initially at $18 \%(+)$ and $26 \%(-)$, loses disproportionately more raphid than araphid valves throughout the experiment until the final period.

The greatest changes in relative species abundance were often observed in the initial and final stages of dissolution (assemblages 1, 2, and 4). Assemblage 3 showed relatively little change in species composition after disappearance of fragile Nitzschia spp., which may be due to incomplete dissolution (50\% valves and $40 \% \mathrm{BiSi}$ remaining in the final sample).

\subsubsection{Assemblage valve abundance and biogenic silica}

Generally, less than $20 \%$ of the valves remain by the end of the experiments between, except for assemblage 3. Loss is especially rapid in the early stages, even where there is relatively little change in species composition. Population decline appears exponential with time. BiSi tends to follow valve abundance decline, but generally underestimates valve losses.

\subsubsection{Dissolution indices and species diversity}

The morphological preservation index, $F$, drops during the course of the experiments from about $0.8-0.9$ to around 0 (assemblages 1 and 4 ) or $\sim 0.5$ (2 and 3), but is relatively insensitive to population or $\mathrm{BiSi}$ losses in the earliest phases of dissolution (Figure 2). Assemblages 3 and 4 show dissolution index values that either fluctuate or only gradually decline until $30-50 \%$ of initial valve numbers have disappeared.

Within assemblages, $R_{\mathrm{wg}}$ and especially $R_{\mathrm{w}}$ values tend to decrease (representing a shift to more ro- 

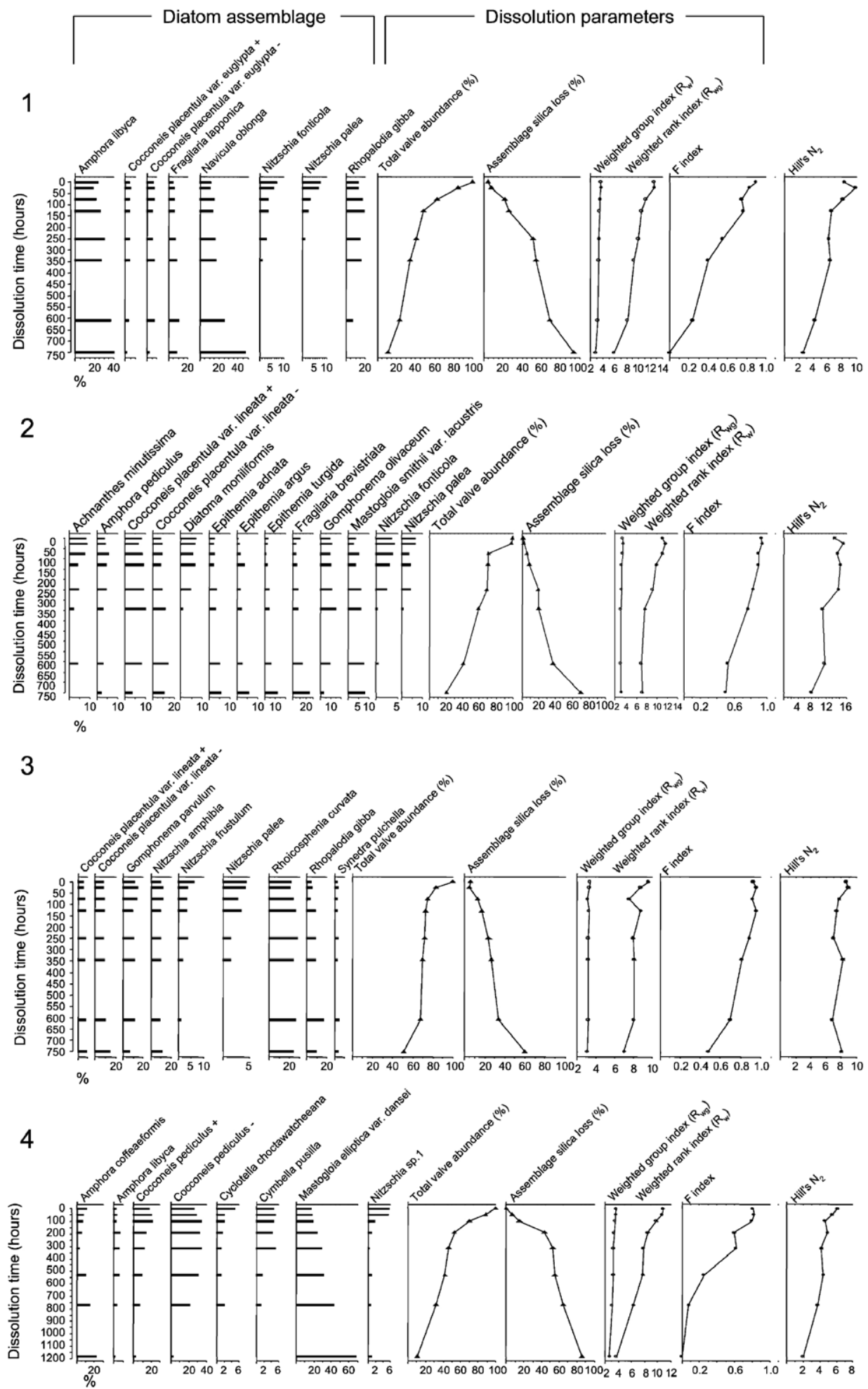

Figure 2. Summary of changes for representative dissolution experiments, assemblages $1-4$. Diatom taxa above $5 \%$ are shown together with dissolution parameters for each sample (total valve abundance, assemblage BiSi loss, and preservation indices $F, R_{\mathrm{wg}}$, and $R_{\mathrm{w}}$ ) and Hill's $N_{2}$. 
bust species) in response to increasing dissolution, although less dramatically than population decline. The absolute values differ considerably between assemblages. $N_{2}$ similarly tends to fall as dissolution progresses, as susceptible taxa disappear and a few robust forms dominate (assemblages 1 and 4), although not uniformly.

\subsection{Dissolution ranking}

Applying Equation (1) to the 37 observed sequences of taxon abundance change, 27 (73\%) had a significant fit to an exponential decay model, with 10 cases (27\%) not significant. Figure 3 shows four examples of raw data and modeled exponential population decay curves for significant $\beta$ values. Rapid decline is typified by Nitzschia palea (Figure 3a, $\beta=0.015$ ), and becomes progressively less dramatic as $\beta$ become smaller (Figure 3b, Cyclotella meneghiniana: $\beta$ $=0.007$; Figure 3c, Cymbella pusilla: $\beta=0.003$; Figure 3d, Amphora pediculus: $\beta=0.002$ ).
A dissolution ranking scheme for 24 taxa (Table 1) was derived from the significant models by using $\beta$ values, weighted by initial percentage in assemblages where taxa appeared in more than one assemblage $\left(\beta_{\mathrm{w}}\right.$; Nitzschia fonticola and $N$. palea with 2 and 3 models, respectively). From these $\beta$ values, the dissolution half-life was also calculated, in experimental hours. Initial $F$ values for taxa $\left(F_{0}\right)$ show that most valves were in good condition at the start of the experiments (mean taxon $F_{0}=0.93$ excluding Cyclotella choctawatcheeana). C. choctawatcheeana valves in assemblage 4 were all badly dissolved $\left(F_{0}\right.$ $=0$; see Section 4) and thus $N$. fonticola is taken as the standard against which relative susceptibility is calculated.

Relative resistance values vary by a factor of about 20, although almost all taxa are within a range of one order of magnitude. Although values generally change gradually between ranks, there are some clear steps in the continuum, most notably associated with the more resistant taxa, e.g. the thresh-
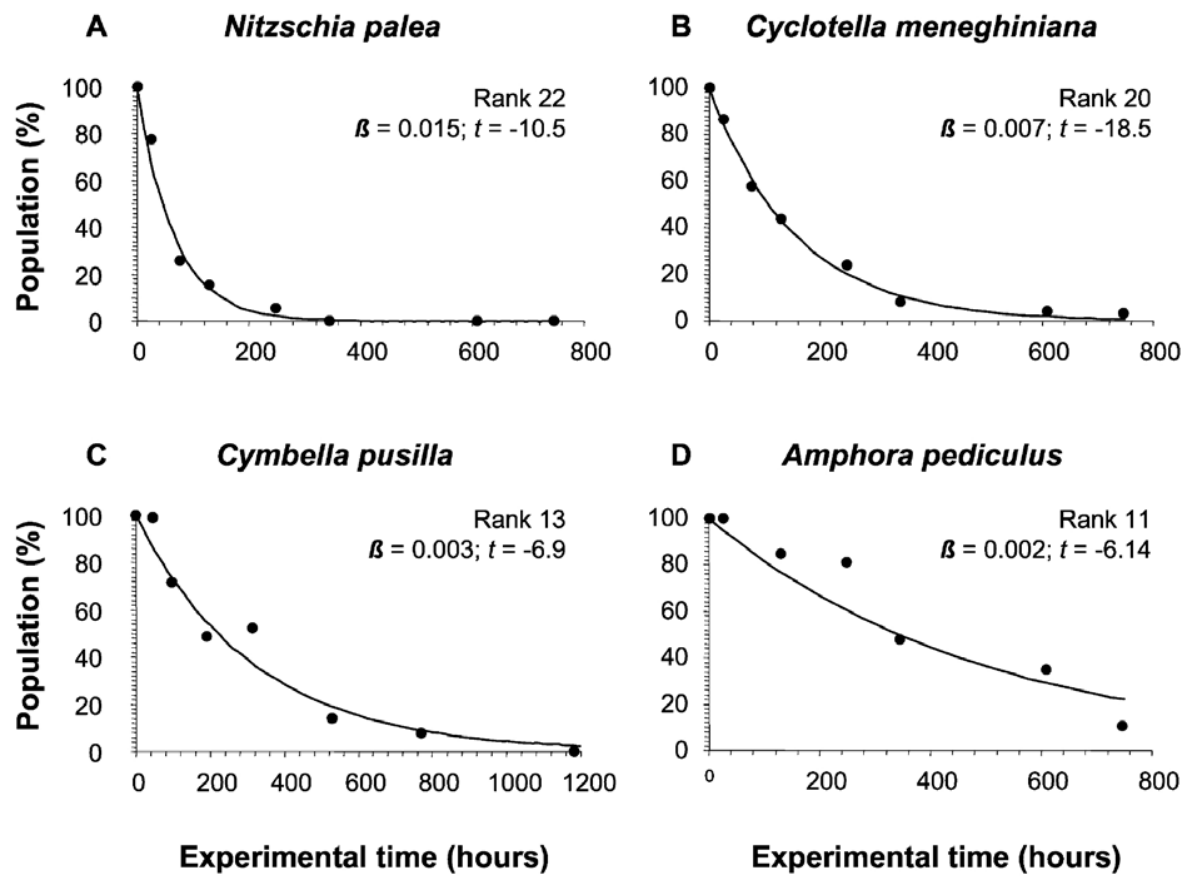

Figure 3. Model output for four significant cases, using Equation (1). (a) Nitzschia palea (assemblage 1, rank 22); (b) Cyclotella meneghiniana (assemblage 1, rank 20); (c) Cymbella pusilla (assemblage 4, rank 13); (d) Amphora pediculus (assemblage 2, rank 11). Population (as \% of original at time $t_{0}$ ) is plotted against experimental dissolution time (h). Calculated $\beta$ and $t$ values are also shown. 
old between Mastogloia elliptica var. dansei (rank 1), and Nitzschia amphibia (rank 2). Rank data were smoothed by grouping into five susceptibility classes (Table 1).

Many morphologically similar taxa are closely ranked in resistance, with finer and smaller forms (e.g. fine Nitzschia taxa, Achnanthes minutissima and Diatoma moniliformis) ranked as least resistant in contrast to larger or more silicified taxa (e.g. Navicula oblonga, Amphora libyca, and C. placentula var. lineata). There is considerable inter-specific variation in susceptibility among the three species of the genus Cocconeis included (C. placentula var. euglypta, var. lineata, and $C$. pediculus). For these species, where identification of heterovalves was possible throughout dissolution, results suggest there is also considerable intra-specific variation. $C$. placentula var. euglypta and var. lineata raphid (+) valves are more resistant than araphid (-) valves, while the opposite was found for $C$. pediculus.

\subsection{Predicting dissolution from sample indices}

The usefulness of various indices as predictors of dissolution was examined by exploring the correlation between sample dissolution and diversity indices ( $F, R_{\mathrm{w}}, R_{\mathrm{wg}}$, and Hill's $N_{2}$ ) and both relative assemblage valve abundance and BiSi dissolved (percentage of original), as experimental measures of dissolution for all samples $(n=32)$. Dissolution parameters are only weakly related to Hill's $N_{2}$ (abundance: $r^{2}$ $=0.24$; BiSi: $r^{2}=0.39 ; p=0.01$ ), but more strongly (at $p=0.001$ ) to both $R_{\mathrm{w}}$ (abundance: $r^{2}=0.39$, BiSi:

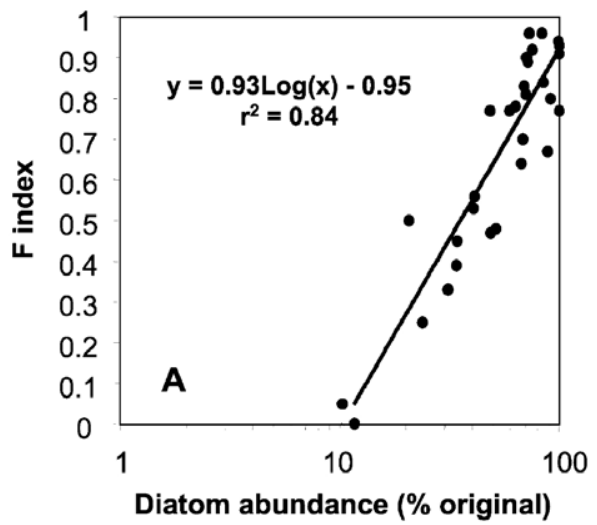

$r^{2}=0.46$ ) and $R_{\mathrm{wg}}$ (abundance: $r^{2}=0.37$, BiSi: $r^{2}=$ 0.48). The strongest relationships $(p<0.001)$, however, are with the $F$ index (abundance: $r^{2}=0.84$, BiSi: $r^{2}=0.89$; Figure 4). Despite considerable taxonomic variation within and between assemblages, the $F$ index is a good predictor of both relative valve and BiSi loss.

\subsection{Application to Devils Lake short core}

An example of a paleolimnological application of these ideas was provided by a short core from Devils Lake, North Dakota (Fritz, 1990). Using the empirical relationships between $F$ and experimental dissolution parameters (Figure 4), fossil sample $F$ values have been used to exemplify trends in relative valve loss and assemblage $\mathrm{BiSi}$, and compared to both DI and measured salinity (Fritz, 1990) at this site since the late 1890s. These results are shown in Figure 5.

The factors controlling the diatom preservation (as assessed by the $F$ index) seem strongly related to salinity at this site. Species composition changes (and hence, DI-salinity) in this core reflect salinity (Fritz, 1990), and high salinity during the Dust Bowl in the 1920s-1930s can be distinguished from much fresher periods in recent decades. However, before about 1950, when $F$ values fall below ca. 0.3 (which is empirically correlated to diatom and BiSi losses of about $70 \%$, Figure 4) the model loses sensitivity and fluctuates between about 15 and $20 \mathrm{~g} \mathrm{l}^{-1}$ over a period when observed salinity fell from $25 \mathrm{~g}^{-1}$ or more to around $8 \mathrm{~g} \mathrm{l}^{-1}$. Lower salinity is accurately reconstructed in

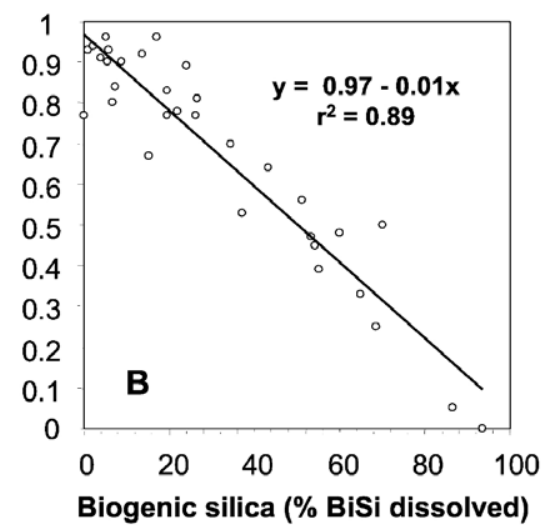

Figure 4. Regressions between $F$ index against (a) assemblage population (as $\%$ of original at $t_{0}$ ) and (b) assemblage BiSi (\% original at $t_{0}$ ) for assemblages $1-4(n=32)$. 


\section{Devils Lake, North Dakota}
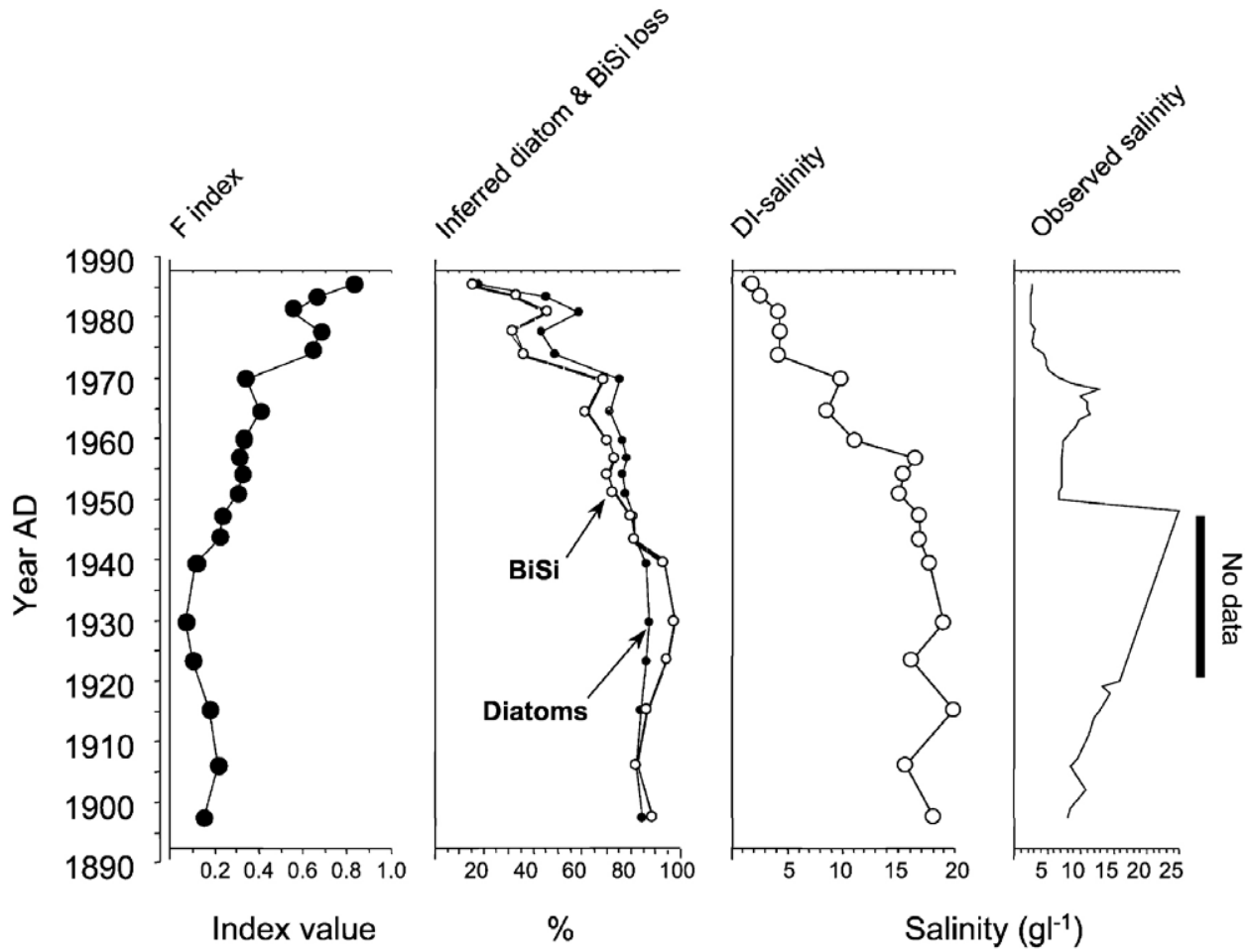

Figure 5. Dissolution parameters ( $F$, and calculated relative diatom abundance and BiSi) compared to diatom-inferred and observed salinity (Fritz, 1990) at Devils Lake, North Dakota. Diatom abundance and BiSi figures are inferred from fossil sample $F$ values (Figure 4).

more recent periods when $F$ values are higher. Minimum values of $F$ occur in samples dated to around 1930 , when there are no measurements of salinity, which may imply losses of up to $80-90 \%$ of valves and BiSi. F index values (and hence, valve and BiSi losses) closely mirror the observed salinity at this site ( $F$ vs. $\log$ (salinity): $r^{2}=0.67, n=15, p<0.001$ ) and exhibit a stronger correlation than between observed and DI salinity $\left(r^{2}=0.4, n=15, p=0.05\right)$.

\section{Discussion}

\subsection{Sources of experimental error}

\subsubsection{Dissolution rate}

Relative abundance data (Figure 2) reflect the relative rates of population decline of taxa in the assemblage. As such a dataset is closed, experiments could only be compared on the basis of common species, whose dissolution behavior is indirectly mediated by other taxa. Modeling of absolute abundance changes during dissolution avoids this problem, if dissolution rates are similar across experimental assemblages.

In the present study, dissolution was not controlled at a constant rate between flasks, although BiSi content was chosen to ensure that dissolution always occurred at high undersaturation. Recent work suggests that dissolution kinetics are complex, and that the assumed linear dependence of dissolution rate on degree of undersaturation is an oversimplification. Classical theory (e.g. Hurd, 1972) underestimates dissolution rate in highly undersaturated solutions, especially involving fresh diatom valves (van Cappellen and Qiu, 1997). Dissolution rate, which differs initially between assemblages because the specific surface area of each assemblage varies, decreases unequally over the course of the experiments according to decreases in the total assemblage surface area and degree of undersaturation of the solutions (Lawson et al. 1978; Kamatani et al. 1988). For these reasons, the mod- 
eled parameters of population decline may differ between assemblages for the same taxon, even where valves are from the same original source. Further experimental work is recommended to verify the rank ordering of these taxa.

Dissolution kinetics in sediments are likely to be far more complex as mineral silicates act as a buffer, contribute to DSi and can affect trace-metal interactions. Dissolution experiments should, therefore, not combine sedimentary or detrital material (often rich in BiSi from valve fragments or girdle bands) with fresh BiSi. Although some of detrital BiSi was included in live samples, the fraction is small. In particular, no epipelic or surface sediments were included, and epipsammic samples were pre-treated to reduce the sedimentary fraction.

\subsubsection{Intra-specific variation}

The range of relative susceptibility reported here ( 20; Table 1) is similar to that observed from dissolution experiments on foraminifera (Adelseck, 1978), radiolarians, and marine diatoms (Johnson, 1974). Attempts to establish rank orderings of taxa assume distinct, stable differences between species that are greater than those within species. Although this is consistent with most studies of microfossil preservation (e.g. Johnson 1974; Malmgrem 1983; Barker et al. 1994), intra-specific differences have been observed (e.g. with foraminifera; Berger 1968; Adelseck 1978). Such differences can be expected for diatoms, if factors that affect resistance to dissolution in the frustule (such as specific surface area and metal ion content within the silica lattice) are highly variable. Mikkelsen (1980) suggested that high latitude populations of the marine diatom Coscinodiscus nodulifer dissolve in a morphologically and proportionately different manner to low latitude samples, based on two replicate sample counts of 300 valves. This has implications for extrapolating global rankings from regional data sets. Lake type may affect diatom robustness as a reflection of variations in water chemistry such as DSi or trace-metal concentrations.

Differences in silicification within a species can also affect dissolution and preservation. Conley et al. (1989) found that BiSi content varied by a factor of 10 within one diatom species. In the current experiments, the robustness of Cyclotella meneghiniana is probably underestimated as the experimental population was dominated by a small morphotype from one lake. A population with a larger average size could be expected to disappear more slowly as average $\mathrm{BiSi}$ surface area:volume ratio is lower (Barker et al., 1994). Gross morphological features, however, may not always accurately reflect important ultrastructural details determining solubility, such as reactive surface area and microporosity (Lawson et al. 1978; van Cappellen and Qiu 1997).

Differences exist between valve types within a species, for example the raphid $(+)$ and araphid (-) valves of Cocconeis taxa. The ratio of these valve types often altered systematically during an experiment, depending on the species. In C. pediculus, raphe canals are preferentially dissolved within apical zones, which may lead to the early break up of the valve. However, in both varieties of C. placentula included in experiments, raphid valves appear as or more resistant than araphid valves (Table 1). Thus, in preservation studies, species counts should be separated into the raphid and araphid forms, where these may represent distinct dissolution taxa with different behavior.

\subsubsection{Initial valve condition}

Ideally, dissolution experiments should be based on well-preserved microfossils if the aim is to study the full dissolution sequence, and compare relative dissolution behavior between species. This is often not possible in practice, and inevitably microfossils in different states of preservation are compared $\left(F_{0}\right.$ values; Table 1) although sample selection and pretreatment attempted to minimize this here.

Variation in susceptibility within populations in the current experiments may reflect differences in life stage or initial valve condition. The proportional rate of population decline is greater than BiSi dissolved in the earlier stages (cf. Barker, 1992), which may reflect losses of both numerically important, but weakly silicified, taxa and partly dissolved valves. Dissolution indices show little change in initially well-preserved assemblages until between 20 and 50\% of valves are lost, in agreement with other experimental observations (Johnson 1974; Adelseck 1978). After this initial period, a threshold appears to be crossed, with indices showing a steady increase in dissolution as population declines. 
This trend is repeated for many individual taxa within each assemblage (Ryves, 1994) and implies that a proportion of valves, even from fresh samples, is particularly sensitive to dissolution. These valves may be dead or senescent cells within the living community (already partly dissolved when collected) or poorly silicified specimens that appear well preserved under LM. The fact that $F_{0}$ values are not all 1 despite sampling living communities implies a small proportion of dissolved valves in the "live samples." Preparation techniques (although gentle) may be partly responsible for initial dissolution, but the fact that more fragile taxa tend to be better preserved initially than more robust taxa (Table 1) argues against this as a major factor, as if this was the case, the opposite would be expected.

Even appreciably dissolved material should reflect major discontinuities in dissolution resistance, allowing partially dissolved assemblages to be placed along the dissolution gradient. In choosing samples and evaluating the results, initial dissolution state should be assessed to compare signs of etching among valves. Where initial taphonomic integrity is unknown, results may be misleading. Assemblage 4 (Figure 2, Table 1) contained ca. $4 \%$ of badly dissolved $C$. choctawatcheeana valves $\left(F_{0}=0\right)$ from an epilithon sample from Medicine Lake (salinity $38.6 \mathrm{~g} \mathrm{l}^{-1}$ ). Values of $\beta$ for this taxon are likely to be overestimated as this population was far advanced along the dissolution pathway. This is supported by other results from a dissolution experiment on surface sediments (but see caveats above) from Medicine Lake (Ryves, 1994) containing well-preserved C. choctawatcheeana valves $(F=0.79)$ which produced much smaller $\beta$ values $(\beta=1.37)$.

\subsection{Dissolution and valve structure}

In open systems and wherever theoretical saturation DSi values exceed assemblage BiSi content, dissolution is independent of valve context and, other things being equal, controlled largely by time. Thus, taxa with greater surface area:volume ratios disappear first (Barker et al., 1994). On a smaller scale, sub-units of a valve that differ in surface area:volume ratios will also disappear in a sequence. Pore fields and areas with high striae density disappear before central areas or apical zones, and spines and fascicles dissolve before interfascicles or costae.

Under SEM, the etching effects of dissolution are clearly visible on valve surfaces, but under LM robust taxa retain morphological integrity, or contain elements that do, and remain distinct as dissolution progresses and $\mathrm{BiSi}$ is lost. "Robustness"' can then be equated to identifiability during BiSi dissolution. Some taxa may dissolve in a series of morphological stages of different specific surface areas and recognizability.

Some species (such as Mastogloia elliptica var. dansei, ranked first, and Navicula oblonga, ranked fourth; Table 1) remain identifiable, even when highly corroded, because the end member has a distinctive morphology, in this case derived from the solid silica plate of the central area with enlarged proximal raphe fissures. Tracking the gradual progress of dissolution allows the development of a dissolution taxonomy, with such forms as dissolution taxa in their own right. In many cases, end stages can be linked through their dissolution sequence to permit identification at generic or species level of fragments that may well have been taxonomically anonymous in isolation. The inference of whole valves from parts is a means of recovering information from a death assemblage blurred by taphonomy.

\subsection{Applications of dissolution data to paleoenviron- mental problems}

Caution should be exercised when extrapolating the results of controlled chemical dissolution beyond the laboratory. Other important site-specific factors affect the wider issue of preservation, such as the role of turbulence, zooplankton grazing, and the abundance and composition of bacterial communities.

Nonetheless, diatom dissolution data can be useful in sediment studies. Dissolution ranking systems for taxa allow sample preservation to be compared by (weighted) averages of ranks of constituent taxa $\left(R_{\mathrm{w}}\right.$ and $R_{\mathrm{wg}}$ ), although samples with different original species composition may be difficult to compare (Figure 2). The approach assumes that differences in rank index are entirely due to preservational differences, rather than species composition. $R_{\mathrm{w}}$ and $R_{\mathrm{wg}}$ can be useful where initial species composition is similar, for example comparing surface sediments at different 
depths within an oceanographic region or lacustrine system, although there are differences in silicification between benthic and pelagic species (Conley et al., 1994). In fact, indices based on assemblage composition (e.g. $R_{\mathrm{w}}, R_{\mathrm{wg}}$, and $N_{2}$ ) rely on differential susceptibility of taxa to record preferential dissolution (loss) of some taxa over others. An assemblage of similarly susceptible species will show little change in such indices during dissolution despite an absolute decline in diatom numbers.

Morphologically-based diatom dissolution indices, such as the $F$ index, have wider use for comparing different assemblages, in space or time, and can generate dissolution profiles for samples and species from surface samples or down cores (Thompson and Saito 1974; Farrell and Prell 1989). The taphonomic integrity of assemblages and dissolution history of each component can be assessed by the congruence of taxon ranks and dissolution indices in the assemblage. Dissolution indices can be used to assess and compare objectively the taphonomic quality of samples. The $F$ index can be applied where dissolution is not extreme $(F>0)$, in conjunction with susceptibility ranking of taxa. Results suggests that the $F$ index is not sensitive in cases of extreme dissolution, where valve loss is over $90 \%$ (Figure 4). Categorizing valves into more than one dissolved state (Ryves, 1994) can permit the development of other indices which can extend taphonomic applications.

Further experimental work (on a greater species diversity, from a wider range of lake types for example) should test the empirical relationships between dissolution state, valve abundance and BiSi loss presented here. Previous experiments (Ryves, 1994), despite including very heterogeneous sample types and diverse species assemblages, are in good agreement with the results reported here between valve abundance and $F$ index, for instance, supporting the idea that these basic relationships have wider utility.

A quantitative assessment of dissolution is a precursor for exploring the multivariate environmental controls on diatom dissolution, for example across a surface sediment dataset (Ryves et al., unpublished). If the relationship between dissolution state ( $F$ index) and BiSi loss (Figure 4) is validated elsewhere, this might aid the understanding and quantification of geochemical Si cycling. Both diatom abundance and
BiSi relationships to the $F$ index should be tested experimentally, and calibrated to different environments and assemblages.

Poor preservation (low $F$ values) can be used as a quantitative criterion by which to flag samples to be treated with caution in reconstructions (Birks et al. 1990; Hall and Smoll 1992; Laird et al. 1998). Similarly, species could be highlighted if calculated optima for an environmental variable are derived from badly preserved occurrences across a dataset, particularly if the quality of preservation is uneven across the environmental gradient. Model residuals between inferred and observed values can likewise be compared to sample preservation in the training set.

The Devils Lake core study (Figure 5) suggests that species composition is a result of both ecological response of the living community to the environment (principally salinity and lake level change) and taphonomic alteration of the death assemblage, especially that due to preferential diatom dissolution. As assemblages will be biased towards robust taxa as they become progressively more dissolved, this will have a disproportionate effect on composition-based inferences in unpredictable ways (Barker, 1992). Even with significant diatom dissolution ( $F$ values $>0.5$ ), the salinity model performs well at this site (Figure 5), but in more dissolved samples, inferred values lose accuracy, even at lower salinity in the early 20th century that are well modeled in upper parts of the core. Thus, errors are not purely (or even mainly) salinity-dependent, but preservationdependent at this site.

At Devils Lake, a threshold is crossed $(F<0.3)$ when preservation has a measurable influence on the reliability of salinity reconstruction, independent of the internal accuracy of the salinity model itself. If the relationships of Figure 4 are broadly correct (given the differences between dissolution experiments and fossil samples), this implies that the model still performs well at this site with up to $50 \%$ of valves (and $\mathrm{BiSi}$ ) lost, although these extrapolations need calibrating. Regardless, the $F$ index is a simple means to identify this threshold, and may help validate model reconstruction at sites without the benefit of an historical record.

Good preservation must be considered the exception rather than the rule. Although the problem of microfossil preservation could be avoided by ignoring 
badly preserved samples (Imbrie and Kipp, 1971), in many situations there is no scope to follow this advice. A dissolved assemblage may be the best available record of the contemporary environment and can still provide ample information. Calibration datasets including dissolved samples are more appropriate for building models, and such transfer functions perform better when applied to dissolved fossil samples, as these include analogues linking modern and fossil datasets (Hutson 1977; Hutson 1978). Adopting this perspective on taphonomy and diagenesis in paleoenvironmental analysis can improve the reconstruction and interpretation of past environments.

\section{Acknowledgements}

We would like to thank Kate Laird for help during fieldwork in the Great Plains and the members of CASPIA for many fruitful discussions on the role of silica dissolution in saline-lake paleolimnology. Much of this work was carried out during a NERC studentship to DBR (GT4/90/ALS/28), with additional support from NERC grant GR9/02033 to DBR and RWB. We thank several people at both UCL and GEUS for constructive comments on the manuscript, particularly Anson Mackay, Emily Bradshaw, Suzanne McGowan, and John Anderson, and Benny Schark (Graphic Department, GEUS) for preparing several of the figures.

\section{References}

Adelseck, C.G. Jr., 1978. Dissolution of deep-sea carbonate: preliminary calibration of preservational and morphological aspects. Deep-Sea Research 24, pp. 1167-1185.

Barker, P., 1992. Differential diatom dissolution in Late Quaternary sediments from Lake Manyara, Tanzania: an experimental approach. Journal of Paleolimnology 7, pp. 235-251.

Barker, P., Fontes, J.-C., Gasse, F. and Druart, J.-C., 1994. Experimental dissolution of diatom silica in concentrated salt solutions and implications for paleoenvironmental reconstruction. Limnology and Oceanography 39, pp. 99-110.

Barker, P., Gasse, F., Roberts, N. and Taieb, M., 1990. Taphonomy and diagenesis in diatom assemblages; a Late Pleistocene palaeoecological study from Lake Magadi, Kenya. Hydrobiologia 214, pp. 267-272.

Battarbee, R.W., 1988. The use of diatom analysis in archaeology: a review. Journal of Archaeological Science 15, pp. 621-644.
Battarbee, R.W. and Kneen, M.J., 1982. The use of electronically counted microspheres in absolute diatom analysis. Limnology and Oceanography 27, pp. 184-188.

van Bennekom, A.J., 1981. On the role of aluminium in the dissolution kinetics of diatom frustules. In: Ross, R. (Ed.), Proceedings of the Sixth Diatom Symposium 1980. Koeltz Science Publ., Koenigstein, pp. 445-454.

Berger, W.H., 1968. Planktonic foraminifera: selective solution and paleoclimatic interpretation. Deep-Sea Research 15, pp. 31-43.

Beyens, L. and Denys, L., 1982. Problems in diatom analysis of deposits: allochthonous valves and fragmentation. Geologie en Mijnbouw 61, pp. 159-162.

Bidle, K.D. and Azam, F., 1999. Accelerated dissolution of diatom silica by marine bacterial assemblages. Nature 397, pp. 508-512.

Birks, H.J.B., Line, J.M., Juggins, S., Stevenson, A.C., and ter Braak, C.J.F., 1990. Diatoms and $\mathrm{pH}$ reconstruction. Philosophical Transactions of the Royal Society of London B 327, pp. 263-278.

van Cappellen, P. and Qiu, L., 1997. Biogenic silica dissolution in sediments of the southern ocean. II. Kinetics. Deep-Sea Research 44, pp. 1129-1149.

Conley, D.J., Kilham, S.S., and Theriot, E.C., 1989. Differences in silica content between marine and freshwater diatoms. Limnology and Oceanography 34, pp. 205-213.

Conley, D.J., Zimba, P.V., Theriot, E., 1994. Silica content of freshwater and marine benthic diatoms. In: Kociolek, J.P. (Ed.), Proceedings of the 11th International Diatom Symposium. California Academy of Sciences, San Francisco, CA, pp. 95-101.

Erez, J., Takahashi, K. and Honjo, S., 1982. In-situ dissolution experiment of Radiolaria in the central North Pacific Ocean. Earth and Planetary Science Letters 59, pp. 245-254.

Farrell, J.W. and Prell, W.L., 1989. Climatic change and $\mathrm{CaCO}_{3}$ preservation: an 800,000 year bathymetric reconstruction from the central equatorial Pacific Ocean. Paleoceanography 4, pp. 447-466.

Flower, R.J., 1993. Diatom preservation: experiments and observations on dissolution and breakage in modern and fossil material. Hydrobiologia 269/270, pp. 473-484.

Flower, R., Likhoshway, Y., 1993. An investigation of diatom preservation in Lake Baikal. In: Grachev, M.A. (Ed.), Fifth Workshop on Diatom Algae, Russian Botanical Society, Irkutsk.

Freiwald, A., 1995. Bacteria-induced carbonate degradation: a taphonomic case study of Cibicides lobatulus from a high-boreal carbonate setting. Palaios 10, pp. 337-346. 
Fritz, S.C., 1990. Twentieth-century salinity and waterlevel fluctuations in Devil's Lake, North Dakota: test of a diatom-based transfer function. Limnology and Oceanography 35, pp. 1771-1781.

Fritz, S.C., Juggins, S. and Battarbee, R.W., 1993. Diatom assemblages and ionic characterization of lakes of the northern Great Plains, North America: a tool for reconstructing past salinity and climate fluctuations. Canadian Journal of Fisheries and Aquatic Sciences 50, pp. 1844-1856.

Fritz, S.C., Juggins, S., Battarbee, R.W., and Engstrom, D.R., 1991. Reconstruction of past changes in salinity and climate using a diatom-based transfer function. $\mathrm{Na}$ ture 352, pp. 706-708.

Gasse, F., Juggins, S., and Khelifa, L.B., 1995. Diatombased transfer functions for inferring past hydrochemical characteristics of African lakes. Palaeogeography, Palaeoclimatology, Palaeoecology 117, pp. 31-54.

Golterman, H.L., Clymo, R.S., and Ohnstad, M.A.M., 1978. In: Methods for Physical and Chemical Analysis of Fresh Waters, Second edition, Blackwell, Oxford, p. 213.

Guiot, J., 1990. Methodology of the last climatic cycle reconstruction in France from pollen data. Palaeogeography, Palaeoclimatology, Palaeoecology 80, pp. 49-69.

Hall, R.I. and Smol, J.P., 1992. A weighted-averaging regression and calibration model for inferring total phosphorus concentration from diatoms in British Columbia (Canada) lakes. Freshwater Biology 27, pp. 417-434.

Hill, M.O., 1973. Diversity and evenness: a unifying notation and its consequences. Ecology 54, pp. 427-432.

Hurd, D.C., 1972. Factors affecting solution rate of biogenic opal in seawater. Earth and Planetary Science Letters 15, pp. 411-417.

Hurd, D.C., Pankratz, H.S., Asper, V., Fugate, J. and Morrow, H., 1981. Changes in the physical and chemical properties of biogenic silica from the central Equatorial Pacific. Part III. Specific pore volume, mean pore size, and skeletal ultrastructure of acid-cleaned samples. American Journal of Science 281, pp. 833-895.

Hutson, W.H., 1977. Transfer functions under no-analog conditions: experiments with Indian Ocean planktonic foraminifera. Quaternary Research 8, pp. 355-367.

Hutson, W.H., 1978. Application of transfer functions to Indian Ocean planktonic foraminifera. Quaternary Research 9, pp. 87-112.

Imbrie, J. and Kipp, N.G., 1971. A new micropaleontological method for quantitative paleoclimatology: application to a late Pleistocene Caribbean core. In: Turekian,
K.K., Editor, 1971. Late Cenozoic Glacial Ages, Yale University Press, New Haven, CT, pp. 71-182.

Johnson, T.C., 1974. The dissolution of siliceous microfossils in surface sediments of the eastern tropical Pacific. Deep-Sea Research 21, pp. 851-864.

Kamatani, A., Ejiri, N. and Treguer, P., 1988. The dissolution kinetics of diatom ooze from the Antarctic area. Deep-Sea Research 35, pp. 1195-1203.

Krauskopf, K., 1982. In: Introduction to Geochemistry (Second edition (International) ed.), McGraw-Hill, Singapore, p. 617.

Krausse, G.L., Schelske, C.L. and Davis, C.O., 1983. Comparison of three wet-alkaline methods of digestion of biogenic silica in water. Freshwater Biology 13, pp. 73-81.

Laird, K.R., Fritz, S.C. and Cumming, B.F., 1998. A diatom-based reconstruction of drought intensity, duration, and frequency from Moon Lake, North Dakota: a subdecadal record of the last 2300 years. Journal of Paleolimnology 19, pp. 161-179.

Lawson, D.S., Hurd, D.C. and Pankratz, H.S., 1978. Silica dissolution rates of decomposing phytoplankton assemblages at various temperatures. American Journal of Science 278, pp. 1373-1393.

Lewin, J.C., 1961. The dissolution of silica from diatom walls. Geochimica et Cosmochimica Acta 21, pp. 182-198.

Lund, J.W.G., Kipling, C. and LeCren, E.D., 1958. The inverted microscope method of estimating algal numbers and the statistical basis of estimations by counting. Hydrobiologia 11, pp. 143-170.

Malmgrem, B.A., 1983. Ranking of dissolution susceptibility of planktonic foraminifera at high latitudes of the South Atlantic Ocean. Marine Micropaleontology 8, pp. 183-191.

Marshall, W.L. and Warakomski, J.M., 1980. Amorphous silica solubilities. II. Effect of aqueous salt solutions at $25^{\circ} \mathrm{C}$. Geochimica et Cosmochimica Acta 44, pp. 915-924.

Mayer, L.M., Jorgensen, J., and Schnitker, D., 1991. Enhancement of diatom frustule dissolution by iron oxides. Marine Geology 99, pp. 263-266.

McIntyre, A., McIntyre, R., 1971. Coccolith concentrations and differential solution in oceanic sediments. In: Reidel, W.R., Funnel, B.M., (Eds.), The Micropalaeontology of Oceans. Cambridge University Press, Cambridge, pp. 253-261.

McMinn, A., 1995. Comparison of diatom preservation between oxic and anoxic basins in Ellis Fjord, Antarctica. Diatom Research 10, pp. 145-151. 
Mikkelsen, N., 1980. Experimental dissolution of Pliocene diatoms. Nova Hedwigia 33, pp. 893-907.

Patrick, S. and Holding, A.J., 1985. The effect of bacteria on the solubilization of silica in diatom frustules. Journal of Applied Bacteriology 59, pp. 7-16.

Peterson, L.C. and Prell, W.L., 1985. Carbonate dissolution in recent sediments of the eastern equatorial Indian Ocean: preservation patterns and carbonate loss above the lysocline. Marine Geology 64, pp. 259-290.

Pichon, J.-J., Bareille, G., Labracherie, M., Labeyrie, L.D., Baudrimont, A. and Turon, J.-L., 1992. Quantification of the biogenic silica dissolution in Southern Ocean sediments. Quaternary Research 37, pp. 361-378.

Round, F.E., 1964. The diatom sequence in lake deposits, some problems of interpretation. Verhandlungen Internationale Vereinigung für Theoretische und Angewandte Limnologie 15, pp. 1012-1020.

Ryves, D.B., 1994. Diatom dissolution in saline lake sediments: an experimental study in the Great Plains of North America. PhD Thesis. University College, London, 306 pp.
Ryves, D.B. and Battarbee, R.W., 1997. Assessing the impact of diatom dissolution in biasing quantitative salinity reconstructions from saline lake sediments. Environmental Change Research Center Research Report 38, University College London.

Samtleben, C., Schafer, P., Andruleit, H., Baumann, A., Baumann, K.-H., Kohly, A., Matthiessen, J. and Schroder-Ritzau, A., 1995. Plankton in the NorwegianGreenland Sea: from living communities to sediment assemblages - an actualistic approach. Geologisch Rundschau 84, pp. 108-136.

Shemesh, A., Burckle, L.H. and Froelich, P.N., 1989. Dissolution and preservation of Antarctic diatoms and the effect on the sediment thanatocoenoses. Quaternary Research 31, pp. 288-308.

Thompson, P.R. and Saito, T., 1974. Pacific Pleistocene sediments: planktonic foraminifera dissolution cycles and geochronology. Geology 2, pp. 333-335. 